\title{
Building Quality, Building Green: Conventions Theory and Industry Transformation
}

\author{
Julie Cidell
}

Julie Cidell, Department of Geography, University of Illinois at Urbana-Champaign, USA (Jcidell@illinois.edu)

\begin{abstract}
Abstrcat
Conventions theory was developed in part to explain how heterogeneous actors with asymmetrical information manage to carry out economic transactions. In particular, how do these actors work together to reduce uncertainty about the quality of the commodities involved? While most applications of conventions theory have been in the agro-food industry, this paper looks at the newly developing green building industry as an example of economic production that relies on multiple constructions of quality in its production and consumption processes. Previous work has shown that conflicts over quality often arise when the parties involved are operating under different conventions, a danger with the multiple actors that must cooperate to produce (and consume) a green building. Furthermore, in the case of green buildings, uncertainty about a product's performance does not end at the point of transaction; the quality of many of the materials or processes involved can only be proven over time. I argue that the producers of green buildings and green building materials have overcome the problems of a) uncertainty over time and b) conflicts over the meaning of quality by drawing on all four conventions simultaneously. Furthermore, this simultaneous incorporation of trust, third-party standards, price, and the common good, as enacted through the Leadership in Energy and Environmental Design (LEED) standards of the U.S. Green Building Council (USGBC), is one of the main reasons for the phenomenal growth of the green building industry among public, private, and non-profit clients.
\end{abstract}

Keywords: quality, building industry, green buildings, conventions theory

\section{Introduction}

The number of building owners applying for green building certification from the U.S. Green Building Council (USGBC)'s Leadership in Energy and Environmental Design (LEED) program has grown exponentially over the last decade. A "green building" takes the environment into account when producing a permanent structure. This includes conserving energy and water, reducing waste and emissions, and promoting a healthy indoor environment, all of which have become factors in defining the quality of a building. How do the different motivations of a building's owner, occupants, designer, and builder combine to produce a structure that is more friendly to the environment, and in the process produce a better understanding of what a "green building" is? As a preliminary step, this paper focuses on companies in the architecture, contracting, and engineering industries and the justifications they offer for their prospective clients to build green.

The answer comes through the framework of conventions theory (CT), which explains why and how economic transactions depend on more than price. Actors draw on justifications based on different conceptualizations of value or worth; for example, in addition to price, how well-known a brand name is or how efficiently a product works. They must then compromise with actors using different justifications, producing temporary arrangements or conventions. Geographers have used CT to look at agrofood and timber products with an emphasis on alternative food networks such as organic 
or local production designations. This paper furthers this work by applying it to green buildings as defined by LEED.

In a parallel argument to Rosin and Campbell (2009), I argue that actors in the green building industry "selectively engage and draw on these [justifications] as they attempt to establish the sector - and their own position within it - within a larger...marketplace" (p. 6). However, the key difference is that instead of seeking to create alternative production networks, green builders are explicitly trying to change the existing system. The USGBC's mission statement is to transform the building industry, not provide an alternative to what is already there. By examining the different justifications that firms use for producing a green building, this paper shows how CT can be used to explain not only new or alternative forms of economic exchange, but how existing forms (and firms) can be transformed through new conventions.

The paper begins with a discussion of the LEED standards and green buildings. This is followed by a review of conventions theory and its geographical applications. The methodology section explains the qualitative methods used in this work. The fifth section explains how green building firms draw on multiple justifications to make the argument for building green. Finally, the conclusion suggests directions for future research.

\section{Leadership in Energy and Environmental Design}

While the concept of green buildings is not new, its codification in standards is. Historically, builders used local materials and built for the climate via passive heating, controlling runoff, or extra insulation. As building styles and materials became standardized and energy became cheaper, less emphasis was placed on buildings' relation to the natural environment. It is only in the last decade or so, as worldwide concern over the environment has grown, that organizations have moved to establish voluntary nationwide standards for building green.

The USGBC was founded in 1993 as a non-profit agency with the mandate of producing national green building standards. By 1998, the LEED standards had been developed and put to use in nine pilot projects. As of the end of 2008, there were about 2,000 certified buildings in the US, with 22,000 more registered, representing about 3 percent of total construction (USGBC 2008). Half of these buildings are registered to private owners with roughly a quarter each from the public and non-profit sectors. This indicates a clear willingness on the part of the private sector to participate in this voluntary scheme. The LEED system is point-based with a few mandatory points and the rest up to the building owner and project manager to choose. Points are available in six categories: sustainable sites, water efficiency, energy and atmosphere, materials and resources, indoor environmental quality, and innovation and design. Based on the number of points earned, a building is designated as either Certified, Silver, Gold, or Platinum. The standards are adjusted every few years, including raising the difficulty level for points that are too easy to earn.

Existing research on green buildings has focused on their effectiveness in achieving various goals - saving energy, reducing employee absenteeism, reducing single-occupancy vehicle use, etc. - or examining the political process by which LEED is carried out in a particular place. Many of these studies are meant to determine the actual costs and benefits of implementing LEED standards in order to encourage their adoption (von Paumgartten, 2003; Edwards, 2006). These studies uniformly show an overall benefit to following LEED standards, not just in the realm of reduced energy costs, but in terms of decreasing student absenteeism and increasing productivity. 
There has been very little work on green buildings from an economic geography perspective. However, green buildings are ripe for study because of how firms in the architecture, contracting, and engineering industries are changing the way they do business in order to meet demands for environmental friendliness at multiple scales. Consumers can choose organic or non-organic apples from one day to the next depending on how much they value multiple criteria, from price to health benefits. But a specific building can either be green or conventional; once it is built, it is built. Rather than presenting alternative or parallel building networks, green builders therefore have to change the existing system. Nevertheless, because of the multiple justifications used in designating a building as green, the theoretical approach of conventions theory that has been used to analyze various agricultural commodities can be of use here.

\section{Justifications and conventions}

Conventions theory (CT) is a theoretical framework that was developed in France in the 1980s (Daviron and Gibbon 2002). Its original focus was trying to explain the uniqueness of labor as a commodity (Wilkinson 1997, Murdoch et al. 2000). It was soon realized, however, that other aspects of economic transactions function under incomplete contracts, and attention turned to the study of uncertainty and risk more generally (Biggart and Beamish 2003, Kirwan 2006). Later scholars began studying the importance of subjective quality measures, in part as examples of uncertainty, but also because the post-Fordist world seemed increasingly to use quality as a competitive measure (Freidberg 2003, Klooster 2006). This included not only the competition which has long defined the marketplace, but the cooperation that exists among actors and institutions (Wilkinson 1997, Boltanski and Thévenot 1991/2006).

Table 1: The worlds or grandeurs according to various authors.

\begin{tabular}{|l|l|l|c|c|c|c|}
\hline & $\begin{array}{l}\text { Boltanski } \\
\text { and } \\
\text { Thévenot } \\
1991 / 2006\end{array}$ & $\begin{array}{l}\text { Thévenot, } \\
\text { Moody, } \\
\text { and Lafaye } \\
\text { 2000 }\end{array}$ & $\begin{array}{l}\text { Klooster } \\
2006\end{array}$ & $\begin{array}{l}\text { Sylvander, } \\
\text { Raikes et } \\
\text { al. 2000 }\end{array}$ & $\begin{array}{l}\text { Murdoch } \\
\text { et al. 2000 }\end{array}$ & $\begin{array}{l}\text { Ponte and } \\
\text { Gibbon } \\
2005\end{array}$ \\
\hline Inspirational & $\mathrm{X}$ & $\mathrm{X}$ & & & & \\
\hline Fame & $\mathrm{X}$ & $\mathrm{X}$ & $\mathrm{X}$ & & $\mathrm{X}$ & \\
\hline Domestic & $\mathrm{X}$ & $\mathrm{X}$ & $\mathrm{X}$ & $\mathrm{X}$ & $\mathrm{X}$ & \\
\hline Industrial & $\mathrm{X}$ & $\mathrm{X}$ & $\mathrm{X}$ & $\mathrm{X}$ & $\mathrm{X}$ & \\
\hline Market & $\mathrm{X}$ & $\mathrm{X}$ & $\mathrm{X}$ & $\mathrm{X}$ & $\mathrm{X}$ & \\
\hline Civic & $\mathrm{X}$ & $\mathrm{X}$ & $\mathrm{X}$ & $\mathrm{X}$ & $\mathrm{X}$ & \\
\hline Green & & $\mathrm{X}$ & $\mathrm{X}$ & & & \\
\hline Financial & & & $\mathrm{X}$ & & & $\mathrm{X}$ \\
\hline Information & & & & & & $\mathrm{X}$ \\
\hline Networked & & & & & & $\mathrm{X}$ \\
\hline
\end{tabular}

Note: this is not meant to be a complete list of all authors who refer to the various worlds suggested, simply a representative listing.

$\mathrm{CT}$ is based on the idea that actors have different motivations for their actions but have to find some sort of common ground in order to enable economic or social transactions. The solution lies in bringing together justifications from different worlds into a formal or information convention, a negotiated agreement that structures the desired transaction. For example, a consumer at a farmer's market may want to establish a personal connection with a grower, while the grower may want to use farming methods that are not harmful to their own health. CT works to explain how they come to a compromise about which conventions to use, such as organic or locally 
grown designations, and how those conventions simultaneously satisfy multiple justifications.

"People engaged in disputes may ascend to six different overarching principles...each of them engaging a full-fledged and coherent definition of what humanity should be" (Latour 1998, p. 224). While the number of these principles varies, Boltanski and Thévenot's original designation of cités or grandeurs, usually translated as "worlds," included six categories; later authors have added more (Table 1). ${ }^{1}$ These worlds each have a justification for action, which can also be thought of as a designation of value or quality.

\section{Worlds of worth}

Inspiration derives worthiness from personal inspiration or belief. Objects are judged to be worthy if they are unique and creative or able to produce an emotional response. For example, in the use of juried competitions for a building or monument, cost, reputation, and technical feasibility may be important, but so too is the affect which the structure produces in its audience.

Being worthy in the world of renown means that you are well-known, that your name or image is recognized. A convention within this world could be the rankings on Amazon.com that tell a potential buyer how many other people have purchased the item they're considering.

The worth or value of a person or object within the domestic world consists of its reputation as distinct from its fame. That reputation is acquired through personal contact and history, thus making domestic conventions somewhat restricted in time and space (Thévenot et al. 2000). An example of the use of the domestic convention is Muslims seeking out a local butcher whom they can personally trust to produce halal meat (Bonne and Verbeke 2008).

The civic world is in some sense the opposite of the domestic. Its higher good is that of the equality of all persons, where the good of the individual is subordinate to that of the collective. Worthiness is measured by how much an object or person furthers the common good, such as consumers choosing a farmer's market to benefit society as a wole (Kirwan 2006).

In the market world, the most familiar to us as consumers, worth is judged by price, which is tested through competition and proven by monetary means. The higher good to which the market world refers is the desires of the individual and their ability to fulfill those desires.

Finally, worth in the industrial world is based on efficiency, performance, and technical optimization. Despite the name, this may or may not take place in an industrial setting. Most certification systems, such as Fair Trade, end up becoming industrial conventions as they stretch across space and employ standardized, performance-based criteria (Bitzer et al., 2008).

In addition to Boltanski and Thévenot's original six worlds, other authors have added the green or sustainable world, where objects are judged as worthy if they are friendly to the environment (Thévenot et al. 2000). However, others argue that the civic, market, and industrial worlds each co-opt elements of the green world and that it cannot stand on its own (Latour 1998, Murdoch et al. 2000). Nevertheless, actors within the green building industry do sometimes justify their actions based explicitly on environmental preservation, so in this paper this is considered as a separate world.

\footnotetext{
${ }^{1}$ While Storper and Salais (1997) based their "worlds of production" on the same idea, they focused on conventions defined only in terms of products, not processes or organizations, and are therefore not considered here.
} 
Through negotiation and compromise, actors blend different justifications in forming a convention under which they can all operate. For example, agreeing to make a specific building "green" requires a convention among the owner, designer, builder, and occupants. More generally, the definition of a green building can be considered a convention, with the LEED standards as one codified example. At a higher level, institutions can be thought of as bundles of conventions that endure over relatively long time periods (Biggart and Beamish 2003), such as the USGBC. At the same time, conventions are always subject to renegotiation, which means that the study of their formation and reformation is always in progress.

Despite its name, CT is a framework for analysis rather than a complete theory (Klooster, 2006). In particular, it neglects the role of power in the justification and compromise processes (Freidberg, 2003) and downplays the dominance of the market world above all others (Ponte and Gibbon, 2005). Nevertheless, CT has contributed to our understanding of logics that exist beyond the market (Wilkinson, 1997), shown that there is more to "quality" than quantity and price (ibid.), and shown that quality is not a universal concept (Ponte and Gibbon, 2005). Additionally, "The conventions approach also has the potential to place nature (especially as it is linked to quality) at the center of food chain analysis" (Murdoch et al. 2000; p. 115). I would argue that this should not be limited to food chain analysis, but can encompass any product where nature or the environment are explicitly cited as factors in quality, including green buildings.

\section{Methods}

This paper presents an initial foray into using CT to analyze the emerging green building industry. In order to do so, one specific element was selected for study: how companies in the architecture, contracting, and engineering industries portray themselves and their green building capabilities to potential clients. Specifically, what justifications do they offer for choosing to build green and for selecting their firm to make it happen?

If a landowner wants to construct a green building, they will likely want to work with firms that have expertise in that area. From the firm's perspective, trying to establish themselves as having expertise can take different forms. Using publicity materials such as company brochures, they can present multiple justifications for why they should be considered as experts and why they should be hired for a specific job. Two different data sources were therefore used: company brochures collected at the trade fair portion of the 2007 USGBC conference known as Greenbuild, and the website for each company with a brochure. Brochures were used from firms that included specific information on green building experience and were offering services rather than commodities, while webpage analysis focused on the "sustainable" or "green" page if available. Sixteen firms in all were analyzed.

The brochures and websites were analyzed according to what Rose calls discourse analysis I (Rose, 2005). Using this method, texts are studied for the discourses they help to produce, as opposed to looking at the practices of organizations or actors. Texts are coded according to the themes or ideas they contain, with the codes normally coming out of the texts themselves and not being externally imposed. However, for the current project, the seven worlds were used as codes. In other words, when an argument for building green (or hiring a specific company to do so) was justified based on industrial, domestic, civic, etc., reasons, it was coded as such. For each of the seven worlds, the texts and images that called on it were examined individually, together, and in relation to their context. The results are explored in the following section. 


\section{The worlds of green buildings}

In this preliminary study, the focus is on the worlds or justifications rather than the conventions that bridge them. However, the purpose of this paper is not simply to identify occurrences of text or images that can fit into each of the seven worlds. The point is to show how existing firms justify two different types of transactions - a specific building project they wish to be hired to produce, and the overall concept of a green building - and in so doing, attempt to transform the industry.

It is easy to see how arguments for building green draw on the desires to save money, benefit the public, and reduce environmental impact, all under a set of codified standards. The classic definition of sustainability already incorporates the market, civic, and green worlds; the LEED standards incorporate the industrial world. It may be more challenging to see how emotion, fame, and trust can be used as justifications, which is why this paper concentrates on those three worlds: inspiration, renown, and domestic.

\section{Inspiration}

Firms drew on inspiration in a variety of ways: dedication or commitment to an ideal; green building as "the right thing to do" or "the wave of the future"; pride in the company's work; or testimonials from clients who say "this is the best building we've ever gotten". For example, Green Building Services defines their mission as "the shared belief that expertise and dedication will one day produce buildings than give more than they take". There were many examples of creativity and innovation in meeting LEED requirements through the use of unusual materials (e.g., recycled blue jeans as insulation). In nearly every case, company brochures and websites that drew on the world of inspiration did so in the first few lines of text, indicating an attempt to stand out because of commitment or innovation or some other aspect of affect or emotion that engineers (and architects to some extent) aren't supposed to have. While the inspiration code was used the least number of times in analyzing the textual data, it was by far the most common among the visual data. Many of the images in brochures and websites are meant to inspire feelings of awe or protection for the environment: mountains, trees, and grassy fields all evoke the untouched natural world which green building practices are meant to preserve.

The ambiguity of the inspirational world was clearly visible: "However, the decision to build 'green' needs not be borne solely out of a personal conviction to conserve the earth's finite resources, but rather, from economic considerations as well". The "feel-good" nature of green buildings sometimes appeared as a neutral or even negative factor. There is also riskiness inherent in inspiration; in a case study description, EMC pointed out that "no 'bleeding edge' technology was used," a derogatory term for untested innovation. Inspiration may need to be buttressed with the standbys of market and industrial justification: "Our goal is to change the way architects and engineers work together by breaking the mold and enhancing the architect's design through elegant and simple engineering solutions" (Timmons Design Engineers). The company is "breaking the mold" and providing "elegant...solutions", thus providing value by inspiring both sets of workers to collaborate on something greater than the sum of its parts. At the same time, this is done within a market context ("design", "solutions") and through industry-valued methods ("engineering solutions").

\section{Renown}

Firms spoke of being a recognized leader or visionary, such as being "known for wide use of innovative engineering technologies". The majority of renown-based comments were related specifically to LEED: the first project in a city or region, the 
first project to achieve a certain level of certification, a principal who is a former chair of the USGBC, or a firm that "has engaged and helped lead the LEED movement like perhaps no other firm in the US." Firms did not merely list this evidence of renown, but made use of it to demonstrate their worth. Teknion proclaimed their goal to "advance sustainability in the industry and the world at large by sharing our achievements and initiatives," thus using themselves as an example for others to follow. "EMC has developed such a reputation...that granting agencies often recommend the firm to prospective clients". It is not only a matter of worth being judged through renown, it is who holds a firm in renown: by listing clients such as the Department of Defense, the University of California, or Birkenstock, Swinerton drew on the renown of those organizations to bolster its own worthiness.

Again, there is ambivalence over worth being judged through renown. The downside is popularity for its own sake without any substance behind it: "We carry these values forward not because it is now popular to do so, but because it has always been what we do" (Cermak Peterka Petersen), or "While many in the industry have at least heard of sustainable or Green Building, there is a large number that do not have the practical experience or a solid understanding of what sustainable design and construction really is" (Sollitt Construction). The popularity of a trend alone is not enough to justify spending money on a green building. However, both of these firms elsewhere drew on renown with regards to the firsts or awards they have garnered in their green building practices, indicating that company fame is an acceptable measure of quality.

\section{Domestic}

Domestic worth is like renown in its basis on reputation, but more personallybased; for example, "hands-on, field-tested experience". EMC Engineers described the value of this approach: "frequent on-site quality control inspections...uncovered many technical issues that had to be resolved". Other firms spoke about their "lasting relationships with builders and owners across the country" or the importance of building trust with their clients. These are all examples of judging the value of a firm through the domestic world, calling on trust and longevity as markers of quality.

However, for this industry, potential clients are likely to be coming from outside the immediate locale and therefore cannot rely on local reputation. One of the ways firms tried to overcome this was through connections to the USGBC: being involved from an early date, being a founding member of a local chapter, or having employees who are active in local chapters or participate on national committees. Such connections suggested that the firm and its employees are worthy of trust and confidence because of their insider status with regards to LEED.

The most important way that firms tried to overcome the constraint of distance with regards to establishing domestic worth, however, was through proxies. This could be through quotes from satisfied customers or collaborators, especially when additional contracts would be following from a completed project. More noteworthy were the number of firms who used their own practices as an example of their domestic worth, such as brochures indicating they were printed using post-consumer recycled paper, soy ink, Forest Stewardship Council-certified paper, or even carbon-neutral paper. Other companies listed practices within their firm such as obtaining ISO 14001 certification or using alternatively-fueled cars for the company fleet. Finally, and most importantly, a few companies mentioned that their own buildings are LEED-certified. These demonstrations that green building firms practice what they preach are attempting to overcome the major limitation of the domestic world: limited spatial reach. These 
companies are reaching out to potential clients they don't already know and with whom they have no easy way of establishing face-to-face trust. Instead, they use themselves as a surrogate. By designing and/or building a structure that they themselves work in, they are demonstrating that they trust their own methods and skills enough to make use of them. Worth in the domestic world is based on personal reputation and demonstrated trustworthiness. To an outsider at a distance, the only way this can be substituted is for the firm to demonstrate that they trust themselves.

\section{Conclusion}

As environmental concerns are increasingly incorporated into production processes, there are multiple ways for firms and industries to do so. While one approach is through alternative production networks, such as organic and fair trade within the agro-food sector, another route is to change existing production and consumption practices. The green building industry is an example of existing firms changing their practices in order to be more environmentally friendly, drawing on multiple justifications and worlds as defined by conventions theory to argue why they should be hired to produce a green building. Such a transformation may be considered as catching up to Europe rather than transforming the global building industry: "What might appear to be a stretch for US design teams is considered normal design practice in the United Kingdom, Germany, and other countries" (Yudelson 2009). Nevertheless, considering that the percentage of new buildings in the US considered to be green has risen to 25 percent, a domestic transformation is well underway (McGraw-Hill 2010).

While the market, civic, green, and industrial worlds of CT are easy to see through mentions of sustainability and standardization, the worlds of inspiration, renown, and domesticity may be more difficult to discern. However, as this paper has shown, firms do draw on these three worlds as well, arguing that creativity, awardwinning performance, and self-trust should also be motivations for choosing them to assist with a specific project. Through selectively drawing on different worlds and bolstering the weaknesses of one (such as the fleeting nature of fame) with the strengths of another (such as the more enduring nature of codified standards), firms are seeking to transform themselves and their industry, not by providing alternative networks of building production, but through changing the practices and processes that produce all buildings.

Because this industry is both physically widespread and tied to local environments, it also provides an opportunity to more carefully consider how spatiality matters to conventions theory. For example, while quality in the domestic world has been thought to be limited in terms of spatial reach, this paper has shown that there are ways actors can extend that reach. Specifically, by using their own work as examples of quality, perhaps by designing their own facilities to meet LEED standards, firms demonstrate themselves as trustworthy and with a sound reputation. Expanding the use of CT within economic geography beyond the agro-food sector can therefore not only enhance our understanding of industry, but of this theoretical framework as well.

\section{References}

Biggart, N. and Beamish, T. (2003). The economic sociology of conventions: habit, custom, practice, and routine in market order. Annual Review of Sociology, 29, 443-464.

Bitzer, V., Francken, M. and Glasbergen, P. (2008). Intersectoral partnerships for a sustainable coffee chain: Really addressing sustainability or just picking (coffee) cherries? Global Environmental Change, 18(2), 271-284. 
Boltanski, O. and Thevenot, L. (1991/2006). De la Justification: Les Economies de la Grandeur. Paris: Gallimard.

Bonne, K. and Verbeke, W. (2008). Religious values informing halal meat production and the control and delivery of halal credence quality. Agriculture and Human Values, 25(1), 35-47.

Daviron, B. and Gibbon, P. (2002). Global commodity chains and African export agriculture. Journal of Agrarian Change, 2(2), 137-161.

Edwards, B. (2006). Benefits of Green Offices in the UK: Analysis from Examples Built in the 1990s. Sustainable Development, 14, 190-204.

Freidberg, S. (2003). Culture, conventions and colonial constructs of rurality in southnorth horticultural trades. Journal of Rural Studies, 19(1), 97-109.

Kirwan, J. (2006). The interpersonal world of direct marketing: Examining conventions of quality at UK farmers' markets. Journal of Rural Studies, 22(3), 301-312.

Klooster, D. (2006). Environmental certification of forests in Mexico: The political ecology of a nongovernmental market intervention. Annals of the Association of American Geographers, 96:3, 541-565.

Latour, B. (1998). To modernise or ecologise? That is the question. In Braun, B. and Castree, N., eds. Remaking Reality: Nature at the Millenium. New York: Routledge.

McGraw-Hill Construction. (2010). Press Release: Green building market grows 50\% in two years despite recession, says McGraw-Hill Construction report. Accessed December 15, 2010. Available online at http://construction.com/AboutUs/2010/1112pr.asp.

Murdoch, J., Marsden, T. and Banks, J. (2000). Quality, nature, and embeddedness: Some theoretical considerations in the context of the food sector. Economic Geography, 76(2), 107-125.

von Paumgartten, P. (2003). The business case for high-performance green buildings: Sustainability and its financial impact. Journal of Facilities Management, 2(1), 26-34.

Ponte, S. and Gibbon, P. (2005). Quality standards, conventions and the governance of global value chains. Economy and Society, 34(1), 1-31.

Rose, G. (2005). Visual Methodologies: An Introduction to the Interpretation of Visual Materials. 2nd edition. London: Sage.

Rosin, C. and Campbell, H. (2009). Beyond bifurcation: examining the conventions of organic agriculture in New Zealand. Journal of Rural Studies, 25:1, 35-47.

Thévenot, L., Moody, M. and Lafaye, C. (2000). Forms of Valuing Nature: Arguments and Modes of Justification in French and American Environmental Disputes. In Lamont, M. and Thévenot, L., Rethinking Comparative Cultural Sociology: Repertoires of Evaluation in France and the United States. Cambridge: Cambridge University Press.

USGBC. (2008). CertifiedProjectList. Accessed December 31, 2008. Available online at http://www.usgbc.org/LEED/Project/CertifiedProjectList.aspx.

Wilkinson, J. (1997). A new paradigm for economic analysis? Recent convergences in French social science and an exploration of the conventions theory approach with a consideration of its application to the analysis of the agrofood system. Economy and Society, 26(3), 305-339.

Yudelson, J. (2009). Green Building Trends: Europe. Washington, DC: Island Press. 